\title{
Low cost activated carbon prepared from Dipterocarpus alatus fruit
}

\author{
Yuvarat Ngernyen ${ }^{1}$, Andrew J. Hunt ${ }^{2}$, Ketsara Silakate ${ }^{1}$, Chantakorn Patawat ${ }^{1}$, Werawit Phiewruangnont ${ }^{1}$, \\ Narathorn Mahantadsanapong ${ }^{1}$, Somchai Chuan-Udom ${ }^{3}$
}

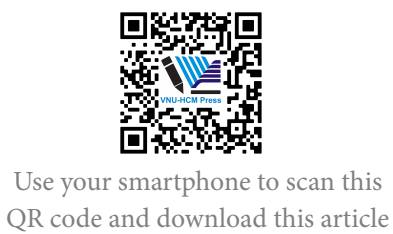

${ }^{l}$ Biomass \& Bioenergy Research Laboratory, Department of Chemical Engineering, Faculty of Engineering, Khon Kaen University, Khon Kaen, 40002, Thailand

${ }^{2}$ Department of Chemistry, Faculty of Science, Khon Kaen University, Khon Kaen, 40002, Thailand

${ }^{3}$ Department of Agricultural Engineering, Faculty of Engineering, Khon Kaen University, Khon Kaen, 40002, Thailand

Correspondence

Yuvarat Ngernyen, Biomass \& Bioenergy Research Laboratory, Department of Chemical Engineering, Faculty of Engineering, Khon Kaen University, Khon Kaen, 40002, Thailand

History

- Received: 09-12-2019

- Accepted: 18-12-2020

- Published: 31-12-2020

DOI : 10.32508/stdjet.v3iSI3.641

\section{Check for updates}

Copyright

(C) VNU-HCM Press. This is an openaccess article distributed under the terms of the Creative Commons Attribution 4.0 International license.

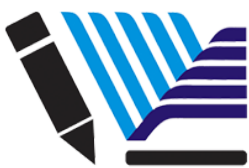

VNU-HCM Press

\begin{abstract}
Dipterocarpus alatus tree grows prolifically throughout Thailand and can be tapped to yield significant quantities of oil to be used as natural diesel. However, such practices lead to waste dried fruit dropping from the tree. At present, there is no utilization of this dropped fruit, therefore costeffective processes need to be applied to obtain higher value products from this waste. A possible to utilization is the conversion to activated carbon for adsorption applications including the removal of heavy metals, dyes, and other contaminants in water purification and other decontamination process. A major challenge of current commercial activated carbon is the high production cost and recently it has been shown that chemical activators comprise a significant proportion of these costs. This feasibility study investigates the use of Dipterocarpus alatus fruit as raw material to produce low cost activated carbon adsorbents. Activated carbon was prepared from Dipterocarpus alatus fruit: endocarp, mesocarp, and wing by chemical activation with $\mathrm{ZnCl}_{2}, \mathrm{FeCl}_{3}$, and $\mathrm{KOH}$. Each part of the fruit was impregnated with $30 \mathrm{wt} \%$ activating agent at a ratio of 1:2 for $1 \mathrm{~h}$ and then carbonized at $500^{\circ} \mathrm{C}$ for a further $1 \mathrm{~h}$. The surface area, pore volume, and average pore size of the resulting carbons were characterized by nitrogen gas adsorption. Activation of mesocarp with $\mathrm{ZnCl}_{2}, \mathrm{KOH}$, and $\mathrm{FeCl}_{3}$ gave activated carbons with the surface area of 447, 256, and 199 $\mathrm{m}^{2} / \mathrm{g}$, respectively. In the same way, $\mathrm{ZnCl}_{2}$ activation gave a maximum surface area of 312 and $278 \mathrm{~m}^{2} / \mathrm{g}$ for wing and endocarp, respectively. All of the aforementioned samples have an average pore size of around $2 \mathrm{~nm}$. In contrast, $\mathrm{KOH}$ and $\mathrm{FeCl}_{3}$ activation of wing and endocarp produced activated carbon with very low surface area (below $25 \mathrm{~m}^{2} / \mathrm{g}$ ), but with an average pore size of 5$14 \mathrm{~nm}$. The maximum surface area of activated carbon prepared from Dipterocarpus alatus fruit was higher than some literature examples for activated carbon from other biomass. Consequently, Dipterocarpus alatus fruit demonstrated significant potential as a feedstock for the preparation of low cost activated carbons.
\end{abstract}

Key words: Dipterocarpus alatus fruit, activated carbon, chemical activation, surface area

\section{INTRODUCTION}

Dipterocarpus alatus tree grows prolifically throughout Thailand and can be tapped to yield significant quantities of oil to be used as natural diesel. However, such practices lead to waste dried fruit dropping from the tree. At present, there is no utilization of this dropped fruit, therefore cost-effective processes need to be applied to obtain higher value products from this waste.

A possible to utilization is the conversion to activated carbon for adsorption applications including the removal of heavy metals, dyes, and other contaminants in wastewater treatment ${ }^{1}$.

A major challenge of current commercial activated carbon is the high production cost and recently it has been shown that chemical activators comprise a significant proportion of these costs ${ }^{2}$. Significant research has focussed on reducing the production cost of activated carbon. Efforts to identify of low cost alternative precursors to traditional feedstocks such as coal have been extensively investigated. Agricultural and forest wastes such as corncob ${ }^{3}$, cola nut shell $^{4}$, Ficus carica bast ${ }^{5}$, plantain fruit stem ${ }^{6}$, Macoré fruit shell ${ }^{7}$, date seed ${ }^{8}$ and Eucalyptus camaldulensis wood $^{9}$ have demonstrated great interest due to their accessibility and abundant availability. To the best of the author's knowledge no research on the preparation of activated carbon prepared from Dipterocarpus alatus fruit have been reported in the literature.

There are two methods for activated carbon production can be employed, physical and chemical activation. Physical activation consists of carbonization of the raw material followed by activation with steam, carbon dioxide or air at high temperature of 800 $1000^{\circ} \mathrm{C}$. In the chemical activation method, the feedstock is soaked in a chemical activating agent such as 
$\mathrm{H}_{3} \mathrm{PO}_{4}, \mathrm{ZnCl}_{2}, \mathrm{KOH}, \mathrm{NaOH}$ and $\mathrm{H}_{2} \mathrm{SO}_{4}$ prior to carbonisation at temperatures in the range of $400-800$ ${ }^{o} \mathrm{C}$.

This preliminary study aims to demonstrate feasibility of the using of $D$ ipterocarpus alatus fruit as raw material for the preparation of low-cost activated carbon. A one-step process, with lower activation temperature will be employed that leads to higher yields and development of extensive porosity ${ }^{10}$. The chemical activators $\mathrm{ZnCl}_{2}, \mathrm{FeCl}_{3}$ and $\mathrm{KOH}$ were selected for production of activated carbon in this work. In order to ensure that cost are kept low a maximum activator to biomass ratio of 2:1, was utilised in this study. The resultant activated carbons were determined their pore structure and proximate analysis.

\section{MATERIALS AND METHODS}

\section{Materials}

$D$ ipterocarpus alatus fruits were collected from Khon Kaen University. The fruits divided into 3 parts: endocarp, mesocarp and wing as shown in Figure 1. Each part was cut into small piece and sieved with the size lower than $4 \mathrm{~mm}$ (mesh no. 5).

\section{Preparation of activated carbon}

$10 \mathrm{~g}$ of the of $D$ ipterocarpus alatus fruit sample was mixed with $30 \mathrm{wt} \% \mathrm{ZnCl}_{2}, \mathrm{FeCl}_{3}$ or $\mathrm{KOH}$ at a impregnation ratio of sample:activating agent 1:2 for 1 $\mathrm{h}$. It was noted that, at this ratio the chemicals were able to promote activation within the raw material, while leading to no excess unutilised activator. No drying step as employed and the resulting sample was carbonized inside fixed-bed stainless steel reactor (5 $\mathrm{cm}$ in the diameter and $30 \mathrm{~cm}$ in the height) at 500 ${ }^{o} \mathrm{C}$ for $1 \mathrm{~h}$ under high purity flow of nitrogen (200 $\mathrm{cm}^{3} / \mathrm{min}$ ). The chosen carbonization temperature was found from thermal analysis as explained in section 3.1. The sample was washed with distilled water until the solution was $\mathrm{pH}$ neutral. The carbon was then oven dried at $110^{\circ} \mathrm{C}$ for $3 \mathrm{~h}$ and kept in air tight pack for further analysis. The yield of the activated carbon is defined as the ratio of mass of final activated carbon to that of the dried original sample $(10 \mathrm{~g})$.

\section{Characterization}

Thermal stability of endocarp, mesocarp and wing of $D$ ipterocarpus alatus fruit samples were investigated by thermogravimetric analyser or TGA (TGA-50 Shimadzu). A typical analysis was conducted by heating a $10 \mathrm{mg}$ sample up to $700^{\circ} \mathrm{C}$ at a heating rate of $10^{\circ} \mathrm{C}$ $\min ^{-1}$ under $\mathrm{N}_{2}$ at a purge rate of $10 \mathrm{ml} \mathrm{min}^{-1}$.

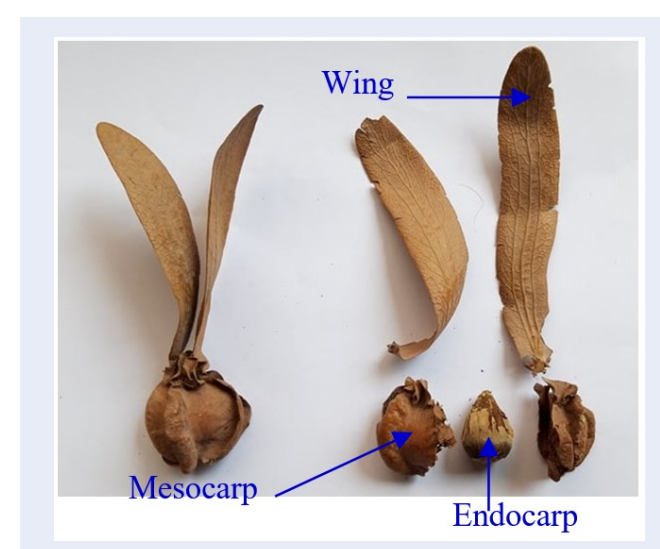

Figure 1: D ipterocarpus alatus fruit and its part.

In order to characterise the BET surface area, pore volume and average pore size of activated carbon, $\mathrm{N}_{2}$ adsorption isotherm at $-196{ }^{\circ} \mathrm{C}$ was determined by gas adsorption analyser (ASAP2460, Micromeritics). Adsorption data were obtained over the relative pressure or $\mathrm{P} / \mathrm{P}^{o}$ ranging from 0.01 to 0.99 . The sample was degassed in a vacuum at $250{ }^{\circ} \mathrm{C}$ for $5 \mathrm{~h}$ before adsorption test. Specific surface area $\left(S_{B E T}\right)$ was calculated using the Brunauer-Emmett-Teller equation. The total pore volume $\left(V_{T}\right)$ was estimated at a $\mathrm{P} / \mathrm{P}^{o}$ of 0.99 . Micropore volume $\left(V_{\text {mic }}\right)$ was determined using t-plot method. Mesopore volume $\left(V_{\text {meso }}\right)$ was calculated by the different between total pore volume and micropore volume. Average pore size $\left(D_{P}\right)$ was obtained by applying Barrett-Joyner-Halenda or BJH method.

Proximate analysis that include moisture, ash, volatile matters and fixed carbon of the raw material and activated carbon was carried out using standard method. The contents of volatile matters and moisture were determined based on ASTM D5832-98 by heated sample at $950^{\circ} \mathrm{C}$ for $30 \mathrm{~min}$ and ASTM D2867 by heated sample at $150{ }^{\circ} \mathrm{C}$ for $3 \mathrm{~h}$, respectively. For ash content, sample was heated at temperature of $800^{\circ} \mathrm{C}$ for $2 \mathrm{~h}^{11}$. Finally, fixed carbon content calculated by the difference as 100 - moisture(\%) - ash(\%) - volatile matters(\%).

\section{RESULTS AND DISCUSSION}

\section{Properties of raw materials}

The proximate analysis of each part of the Dipterocarpus alatus fruit based on the average of three samples was demonstrated in Table 1. For all parts, the content showed similar values; with a moisture content of $8 \mathrm{wt} \%$, volatile matter content of $72-73 \mathrm{wt} \%$, ash $2 \mathrm{wt} \%$ and fixed carbon of $16-17$ 
wt\%. D ipterocarpus alatus fruit exhibit low ash and high volatile contents, similar to other biomass wastes that have already been reported in literature. The fixed carbon content is also higher or comparable with those materials such as oil palm wood $(9.63$ $\mathrm{wt} \%)^{12}$, kenaf core fibre $(11 \mathrm{wt} \%)^{13}$, waste tea $(11.34$ $\mathrm{wt} \%)^{14}$, Eucalyptus camaldulensis wood (14.65 $\mathrm{wt} \%)^{9}$, bagasse $(16.4 \mathrm{wt} \%)^{15}$, barley straw (17.3 $\left.{ }^{w t} \%\right)^{16}$ and rice-straw $(17.8 \mathrm{wt} \%)^{17}$. Therefore, $D$ ipterocarpus alatus fruit is a suitable feedstock for preparation of activated carbon.

The thermal behaviour as analysed by TGA for the endocarp, mesocarp and wing of Dipterocarpus alatus fruit are presented in Figure 2. The TG curve of D ipterocarpus alatus fruit is like that of any other biomass comprised mainly of cellulose, hemicellulose and lignin. It indicates three mass loss steps: the evaporation of adsorbed moisture up to $110^{\circ} \mathrm{C}$, the decomposition of hemicellulose in the biomass at $200-340{ }^{\circ} \mathrm{C}$ and the cellulose decomposition at about $380-500{ }^{\circ} \mathrm{C}^{9}$. It can also be seen that the moisture the evaporated from the structure $10 \mathrm{wt} \%$, which is consistent with the results of proximate analysis. Moreover, the main decomposition occurring between $200-480{ }^{\circ} \mathrm{C}$ is the devolatilisation process resulting in the remaining of carbon content in the structure. Therefore, the suitable temperature for preparation of activated carbon from this fruit should be higher than these temperatures, therefore $500{ }^{\circ} \mathrm{C}$ was used to prepare activate carbon in this work.

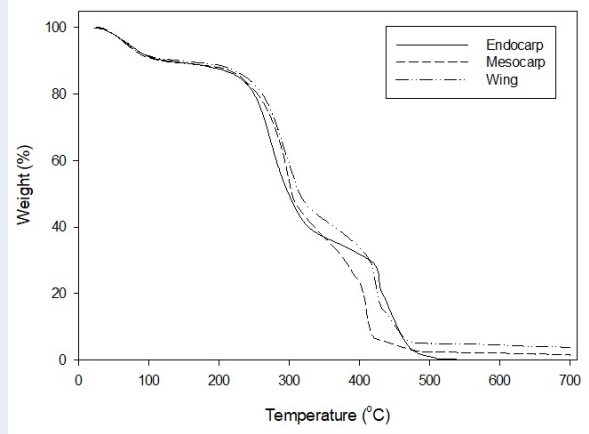

Figure 2: Thermogravimetric analysis plot of each part of the $D$ ipterocarpus alatus fruit

\section{$\mathbf{N}_{2}$ adsorption isotherms and pore structure development}

Figure 3 shows the nitrogen gas adsorptiondesorption isotherms at $-196^{\circ} \mathrm{C}$ of the prepared activated carbons. It is noted that adsorption-desorption isotherms of $\mathrm{KOH}$ activation for endocarp part and $\mathrm{FeCl}_{3}$ activation for wing part were not shown due to very low adsorption volumes. All the adsorption isotherms are of type I according to IUPAC or the International Union of Pure and Applied Chemistry classification, which is characteristic of microporous structures ${ }^{16}$. The adsorption rapidly increases at low relative pressures $\left(\mathrm{P} / \mathrm{P}^{o}<0.1\right)$. The isotherms also exhibited small hysteresis loops implying the existence of mesoporosity. Therefore, all prepared activated carbons are of a micro-mesoporous structure. Although the adsorption isotherms of all samples are similar classification, the adsorption capacities are different depend on type of activating agents. It was observed that $\mathrm{ZnCl}_{2}$ activation had higher $\mathrm{N}_{2}$ adsorption than that of $\mathrm{FeCl}_{3}$ and $\mathrm{KOH}$ activation. The low $\mathrm{N}_{2}$ adsorbed amount for $\mathrm{KOH}$ activation of wing was observed, indicating a less porous structure. Table 2 is summarised the yield, $S_{B E T}, V_{\text {mic }}, V_{\text {meso }}$, $V_{T}$ and $D_{P}$ of all resulting activated carbons. A maximum yield of 43-51 wt\% obtained from $\mathrm{FeCl}_{3}$ activation while $\mathrm{ZnCl}_{2}$ gave the yield of $32-38 \mathrm{wt} \%$. The minimum yield of 16-25 wt\% was recorded for $\mathrm{KOH}$ activation. As mentioned before, $D$ ipterocarpus alatus fruit is a lignocellulosic material, with cellulose, hemicellulose and lignin as the main components. In activation and carbonization steps, these components decompose and liberate the non-carbon elements that is hydrogen, oxygen and nitrogen in the form of liquids and gases, remaining the carbon content ${ }^{18}$. This causes a decrease in mass of the resulting activated carbon when compare with the original material.

For all parts of the Dipterocarpus alatus fruit, textural analysis showed that the activated carbons synthesized with $\mathrm{ZnCl}_{2}$ had greater porosity in term of surface area and total pore volume compare to $\mathrm{FeCl}_{3}$ and $\mathrm{KOH}$ activated samples. It was demonstrated that activated mesocarp with $\mathrm{ZnCl}_{2}$ provide best properties of activated carbon, with BET surface area of $447 \mathrm{~m}^{2} / \mathrm{g}$ and total pore volume of $0.265 \mathrm{~cm}^{3} / \mathrm{g}$. Furthermore, $\mathrm{ZnCl}_{2}$ and $\mathrm{FeCl}_{3}$ activation produced activated carbon with mostly micropore except in the case of $\mathrm{FeCl}_{3}$ activation of wing part. For $\mathrm{KOH}$ activation, resulting activated carbons demonstrated mainly mesoporous except for the mesocarp materials.

The results from Table 2 demonstrate that chemical activation of endocarp and wing with $\mathrm{KOH}$ and activation of wing with $\mathrm{FeCl}_{3}$ obtaining activated carbons with low surface area and pore volume but with a pore size of 5-14 nm. It is suggested that large pore size adsorbent is suitable for adsorbed large molecule adsorbate in adsorption processes. Therefore, the use of such materials for the adsorption of large molecules 
Table 1: Proximate analysis (wt\%) of each part of Dipterocarpus alatus fruit

\begin{tabular}{llll}
\hline & Endocarp & Mesocarp & Wing \\
Moisture & 8.26 & 8.74 & 8.12 \\
Volatile Matter & 73.02 & 72.35 & 72.08 \\
Ash & 2.70 & 2.21 & 2.54 \\
Fixed carbon & 16.02 & 16.70 & 17.26 \\
\hline
\end{tabular}

may overcome diffusion limitations resulting from the small pore size of traditional activated carbons.

The adsorbent pores are classified into three groups: micropore (diameter $<2 \mathrm{~nm}$ ), mesopore (diameter 2$50 \mathrm{~nm}$ ) and macropore (diameter $>50 \mathrm{~nm}$ ) according to the definition of IUPAC. Table 2 demonstrates that the average pore diameter of all activated carbons is between 2 and $14 \mathrm{~nm}$, indicating they are a microporous and mesoporous materials.

For all activating agents, different parts of $D$ ipterocarpus alatus fruit produced activated carbons with varying surface areas and pore volumes. This may be due to the different physical structure of each part. For example, mesocarp is hard compared to the wing part which is very thin.

The maximum surface area of activated carbon prepared from mesocarp of Dipterocarpus alatus fruit $\left(447 \mathrm{~m}^{2} / \mathrm{g}\right)$ was higher than some chemical activated carbons from biomass by such as palm flower (9.57 $\left.\mathrm{m}^{2} / \mathrm{g}\right)^{19}$, branches of walnut wood $\left(32 \mathrm{~m}^{2} / \mathrm{g}\right)^{20}$, oak wood $\left(68 \mathrm{~m}^{2} / \mathrm{g}\right)^{21}$, peanut shell $\left(89 \mathrm{~m}^{2} / \mathrm{g}\right)^{22}$, pine nut shell $\left(296 \mathrm{~m}^{2} / \mathrm{g}\right)^{23}$, kenaf core fiber $\left(299 \mathrm{~m}^{2} / \mathrm{g}\right)^{13}$, macauba seed endocarp $\left(371 \mathrm{~m}^{2} / \mathrm{g}\right)^{23}$ and carnauba palm leave $\left(431 \mathrm{~m}^{2} / \mathrm{g}\right)^{23}$.

\section{Proximate analysis}

According to Table 3, the volatile matters in activated carbon decreased from starting material while fixed carbon increased. This was expected as devolatilisation leads to the loss of oxygen and hydrogen in the form of water during carbonisation and activation resulted in sample containing predominantly carbon. Furthermore, ash content increased from starting material while moisture content decreased. These results were similar to that reported in the work of Ahmad et al. ${ }^{12}$. Low amounts of moisture, volatile matter and ash contents indicate that the activated carbon should be a good raw material for adsorbents ${ }^{6}$. Ash content reduces the activity of activated carbon the lower the ash content; the better activated carbon will be for adsorption $^{6}$
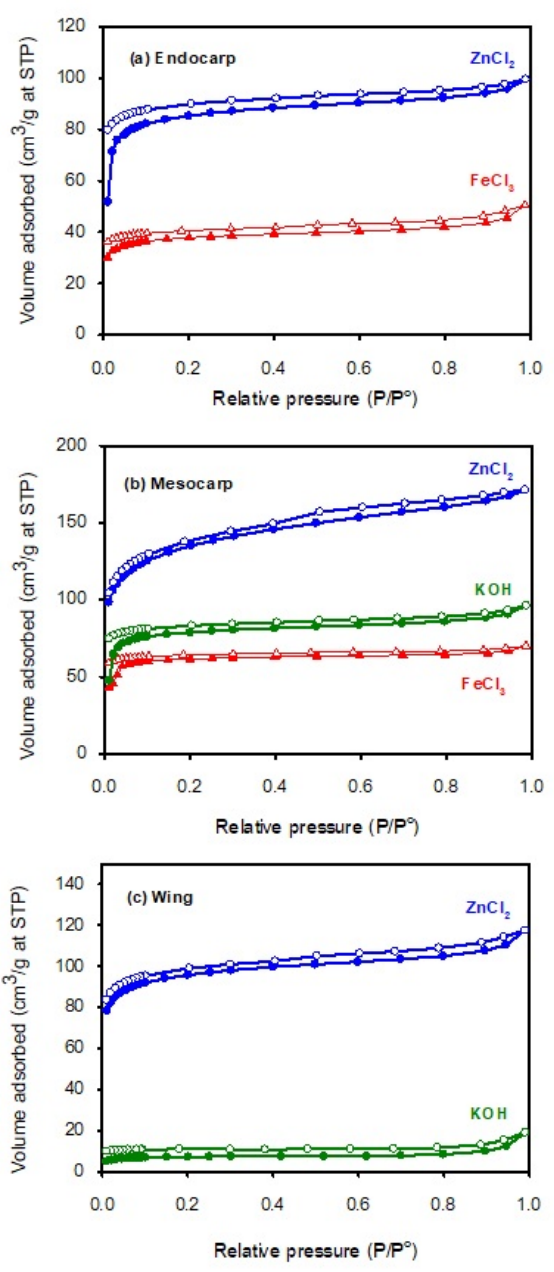

Figure 3: $\mathrm{N}_{2}$ adsorption-desorption isotherms of the prepared activated carbon

\section{CONCLUSION}

In this preliminary study, the production of activated carbon from Dipterocarpus alatus fruit using the chemical activation method with $\mathrm{ZnCl}_{2}, \mathrm{FeCl}_{3}$ and $\mathrm{KOH}$, has been investigated. The maximum BET surface area obtained by $\mathrm{ZnCl}_{2}$ activation was 447, 312 and $278 \mathrm{~m}^{2} / \mathrm{g}$ for mesocarp, wing and endocarp, respectively. In the case of $\mathrm{FeCl}_{3}$ activation, activated 


\begin{tabular}{|c|c|c|c|c|c|c|}
\hline Sample & $\begin{array}{l}\text { Yield } \\
\text { (wt\%) }\end{array}$ & $\begin{array}{l}\text { SBET } \\
\left(\mathrm{m}^{2} / \mathrm{g}\right)\end{array}$ & $\begin{array}{l}\text { Vmic } \\
\left(\mathrm{cm}^{3} / \mathrm{g}\right)\end{array}$ & $\begin{array}{l}\text { Vmeso } \\
(\mathrm{cm} 3 / \mathrm{g})\end{array}$ & $\begin{array}{l}\text { VT } \\
(\mathrm{cm} 3 / \mathrm{g})\end{array}$ & $\begin{array}{l}\mathrm{DP} \\
(\mathrm{nm})\end{array}$ \\
\hline \multicolumn{7}{|c|}{ Endocarp } \\
\hline $\mathrm{ZnCl}_{2}$ & 35 & 278 & $\begin{array}{l}0.101 \\
(66 \%)\end{array}$ & $\begin{array}{l}0.053 \\
(34 \%)\end{array}$ & 0.154 & 2.22 \\
\hline $\mathrm{FeCl}_{3}$ & 51 & 122 & $\begin{array}{l}0.045 \\
(58 \%)\end{array}$ & $\begin{array}{l}0.033 \\
(42 \%)\end{array}$ & 0.078 & 2.55 \\
\hline $\mathrm{KOH}$ & 16 & 2 & $\begin{array}{l}0.001 \\
(25 \%)\end{array}$ & $\begin{array}{l}0.003 \\
(75 \%)\end{array}$ & 0.004 & 13.84 \\
\hline \multicolumn{7}{|c|}{ Mesocarp } \\
\hline $\mathrm{ZnCl}_{2}$ & 32 & 447 & $\begin{array}{l}0.117 \\
(44 \%)\end{array}$ & $\begin{array}{l}0.148 \\
(56 \%)\end{array}$ & 0.265 & 2.37 \\
\hline $\mathrm{FeCl}_{3}$ & 45 & 199 & $\begin{array}{l}0.080 \\
(74 \%)\end{array}$ & $\begin{array}{l}0.028 \\
(26 \%)\end{array}$ & 0.108 & 2.18 \\
\hline $\mathrm{KOH}$ & 25 & 256 & $\begin{array}{l}0.096 \\
(64 \%)\end{array}$ & $\begin{array}{l}0.053 \\
(36 \%)\end{array}$ & 0.149 & 2.33 \\
\hline \multicolumn{7}{|l|}{ Wing } \\
\hline $\mathrm{ZnCl}_{2}$ & 38 & 312 & $\begin{array}{l}0.112 \\
(62 \%)\end{array}$ & $\begin{array}{l}0.070 \\
(38 \%)\end{array}$ & 0.182 & 2.33 \\
\hline $\mathrm{FeCl}_{3}$ & 43 & 6 & $\begin{array}{l}0.002 \\
(15 \%)\end{array}$ & $\begin{array}{l}0.011 \\
(85 \%)\end{array}$ & 0.013 & 8.84 \\
\hline $\mathrm{KOH}$ & 19 & 24 & $\begin{array}{l}0.009 \\
(30 \%)\end{array}$ & $\begin{array}{l}0.021 \\
(70 \%)\end{array}$ & 0.030 & 4.95 \\
\hline
\end{tabular}

Table 3: Proximate analysis (wt\%) of activated carbon prepared by $\mathrm{ZnCl}_{2}$ activation

\begin{tabular}{llll}
\hline & Endocarp & Mesocarp & Wing \\
Moisture & 7.00 & 6.50 & 7.14 \\
Volatile Matter & 25.71 & 26.36 & 27.77 \\
Ash & 8.53 & 7.32 & 8.29 \\
Fixed carbon & 58.76 & 59.82 & 56.88 \\
\hline
\end{tabular}

carbon with surface area of 199 and $122 \mathrm{~m}^{2} / \mathrm{g}$ were produced from the mesocarp and endocarp, respectively, but no porosity was formed for the wing part of the fruit. Regarding the activation with $\mathrm{KOH}$, surface area of activated carbon from mesocarp was $256 \mathrm{~m}^{2} / \mathrm{g}$. However, $\mathrm{KOH}$ activation of the endocarp and wing parts could not develop porosity in activated carbon structure. The activated carbon prepared under the described experimental conditions demonstrates the potentiality of Dipterocarpus alatus fruit as low cost material for the preparation of activated carbon, resulting a surface area higher than that of activated carbons obtained from some biomass wastes.

Future studies will utilise Dipterocarpus alatus fruit activated carbons for adsorption of dye or heavy metal molecules. The preparation conditions such as activator ratio, impregnation time, carbonization temperature and carbonization time should also be investigated.

\section{ACKNOWLEDGEMENT}

This study was supported by Research and Academic Services Affairs of Khon Kaen University under Yang Na Scholarship for fiscal year 2019.

\section{AUTHOR CONTRIBUTIONS}

All authors contributed equally to this work. All authors have read and agreed to the published version of the manuscript. 


\section{CONFLICT OF INTEREST}

We declare that there is no conflict of whatsoever involved in publishing this research.

\section{REFERENCES}

1. Matos M, Barreiro MF, Gandini A. Olive stone as a renewable source biopolyols. Ind. Crop. Prod. 2010;32:7-12. Available from: https://doi.org/10.1016/j.indcrop.2010.02.010.

2. Sangon S, et al. Valorization of waste rice straw for the production of highly effective carbon based adsorbents for dyes removal. J. Clean. Prod. 2018;172:1128-1139. Available from: https://doi.org/10.1016/j.jclepro.2017.10.210.

3. El-Sayed GO, Yehia MM, Asaad AA. Assessment of activated carbon prepared from corncob by chemical activation with phosphoric acid. Water Resources and Industry. 2014;7-8:6675. Available from: https://doi.org/10.1016/j.wri.2014.10.001.

4. Nsami JN, Mbadcam JK. The adsorption efficiency of chemically prepared activated carbon from cola nut shell by $\mathrm{ZnCl} 2$ on methylene blue. Journal of Chemistry, Article ID 469170. 2013;Available from: https://doi.org/10.1155/2013/469170.

5. Pathania D, Sharma S, Singh P. Removal of methylene blue by adsorption onto activated carbon developed from Ficus carica bast. Arab. J. Chem. 2017;p. S1445-S1451. Available from: https://doi.org/10.1016/j.arabjc.2013.04.021.

6. Ekpete OA, Marcus AC, Osi V. Preparation and characterization of activated carbon obtained from plantain (Musa paradisiaca) fruit stem. Journal of Chemistry. 2017;Available from: https://doi.org/10.1155/2017/8635615.

7. Aboua KN, Yobouet YA, et al. Investigation of dye adsorption onto activated carbon from the shells of Macoré fruit. J. Environ. Manage. 2015;156:10-14. PMID: 25791232. Available from: https://doi.org/10.1016/j.jenvman.2015.03.006.

8. Ogungbenro AE, Quang DV, Al-Ali KA, Vega LF, Abu-Zahra MRM. Physical synthesis and characterization of activated carbon from date seeds for $\mathrm{CO} 2$ capture. J. Environ. Chem. Eng. 2018;6:4245-4252. Available from: https://doi.org/10.1016/j. jece.2018.06.030.

9. Heidari A, Younesi H. Adsorptive removal of $\mathrm{CO} 2$ on highly microporous activated carbons prepared from Eucalyptus camaldulensis wood: Effect of chemical activation. J. Taiwan Inst. Chem. Eng. 2014;45:579-588. Available from: https://doi. org/10.1016/j.jtice.2013.06.007.

10. Dąbrowski A, Podkościelny P, Hubicki Z, Barczak M. Adsorption of phenolic compounds by activated carbon - a critical review. Chemosphere. 2005;58:1049-1070. PMID: 15664613. Available from: https://doi.org/10.1016/j.chemosphere.2004. 09.067.

11. Aygün A, Yenisoy-Karakaş S, Duman I. Production of granular activated carbon from fruit stones and nutshells and evaluation of their physical, chemical and adsorption properties. Micropor Mesopor. Mat. 2003;66:189-195. Available from: https://doi.org/10.1016/j.micromeso.2003.08.028.

12. Ahmad AL, Loh MM, Aziz JA. Preparation and characterization of activated carbon from oil palm wood and its evaluation on methylene blue adsorption. Dyes and Pigments. 2007;75:263-
272. Available from: https://doi.org/10.1016/j.dyepig.2006.05. 034.

13. Shamsuddin MS, Yusoff NRN, Sulaiman MA. Synthesis and characterization of activated carbon produced from kenaf core fiber using $\mathrm{H} 3 \mathrm{PO} 4$ activation. Procedia Chem. 2016;19:558-565. Available from: https://doi.org/10.1016/j. proche.2016.03.053.

14. Kan Y, Yue Q, Li D, Wu Y, Gao B. Preparation and characterization of activated carbons from waste tea by $\mathrm{H} 3 \mathrm{PO} 4$ activation in different atmospheres for oxytetracycline removal. J. Taiwan Inst. Chem. Eng. 2017;71:494-500. Available from: https://doi.org/10.1016/j.jtice.2016.12.012.

15. Darmstadt H, Garcia-Perez M, Chaala A, Cao NZ, Roy C. Copyrolysis under vacuum of sugar cane bagasse and petroleum residue properties of the char and activated char products. Carbon. 2001;39:815-825. Available from: https://doi.org/10. 1016/S0008-6223(00)00204-9.

16. Pallarés J, González-Cencerrado A, Arauzo I. Production and characterization of activated carbon from barley straw by physical activation with carbon dioxide and steam. Biomass Bioenerg. 2018;115:64-73. Available from: https://doi.org/10. 1016/j.biombioe.2018.04.015.

17. Oh GH, Park CR. Preparation and characteristics of rice-strawbased porous carbons with high adsorption capacity. Fuel. 2002;81:327-336. Available from: https://doi.org/10.1016/ S0016-2361(01)00171-5.

18. Yakout SM, El-Deen GS. Characterization of activated carbon prepared by phosphoric acid activation of olive stones. Arab. J. Chem. 2016;9:S1155-S1162. Available from: https://doi.org/ 10.1016/j.arabjc.2011.12.002.

19. Nethaji S, Sivasamy A. Adsorptive removal of an acid dye by lignocellulosic waste biomass activated carbon: equilibrium and kinetic studies. Chemosphere. 2011;82:1367-1372. PMID: 21176940. Available from: https://doi.org/10.1016/j. chemosphere.2010.11.080.

20. Ghaedi M, Mazaheri H, Khodadoust S, Hajati S, Purkait MK. Application of central composite design for simultaneous removal of methylene blue and $\mathrm{Pb} 2+$ ions by walnut wood activated carbon. Spectrochim Acta A. 2015;135:479-490. PMID 25113736. Available from: https://doi.org/10.1016/j.saa.2014. 06.138.

21. Hajati S, Ghaedi M, Yaghoubi S. Local, cheap and nontoxic activated carbon as efficient adsorbent for the simultaneous removal of cadmium ions and malachite green: optimization by surface response methodology. J. Ind. Eng. Chem. 2015;21:760-767. Available from: https://doi.org/10.1016/j. jiec.2014.04.009.

22. Al-Othman ZA, Ali R, Naushad M. Hexavalent chromium removal from aqueous medium by activated carbon prepared from peanut shell: Adsorption kinetics, equilibrium and thermodynamic studies. Chem. Eng. J. 2012;184:238-247. Available from: https://doi.org/10.1016/j.cej.2012.01.048.

23. Lacerda VS, et al. Rhodamine B removal with activated carbons obtained from lignocellulosic waste. J. Env. Manage. 2015;155:67-76. PMID: 25770964. Available from: https: //doi.org/10.1016/j.jenvman.2015.03.007. 